\title{
EEF1B2 wt Allele
}

National Cancer Institute

\section{Source}

National Cancer Institute. EEF1B2 wt Allele. NCI Thesaurus. Code C52029.

Human EEF1B2 wild-type allele is located within 2q33-q34 and is approximately $3 \mathrm{~kb}$ in length. This allele, which encodes elong ation factor 1-beta protein, plays a role in the transfer of aminoacylated tRNAs to the ribosome during translation. 